\title{
Pengenalan Teknologi Pertanian Berkelanjutan Kepada Petani Di Lahan Kering Desa Gumantar, Kabupaten Lombok Utara
}

\author{
I Komang Damar Jaya*, Bambang Budi Santoso, Jayaputra
}

\author{
Department of Agronomy, Faculty of Agriculture, University of Mataram, Mataram, Indonesia
}

\author{
Article history \\ Received: 19-01-2021 \\ Revised: 15-02-2021 \\ Accepted: 10-03-2021 \\ *Corresponding Author: \\ I Komang Damar Jaya, \\ Department of Agronomy, \\ Faculty of Agriculture, \\ University of Mataram, \\ Mataram, Indonesia;
}

Email: ikdjaya@unram.ac.id
Abstract: The main obstacle faced in the development of seasonal crops on dryland is the availability of water and low soil fertility. As a result, the cropping index (IP) of dryland is very low because crops are grown in the rainy season only. The use of inorganic fertilizers is also very high in order to obtain adequate crop yields. Such practices can result in a reduction in the organic carbon content in the soil in the long term. Soil fertility can be maintained if the soil contains a lot of organic carbon. Organic carbon in the soil can increase soil fertility by preventing nutrient loss, increasing soil physical stability, increasing the soil's ability to retain water and increasing the consortium of microorganisms. An introduction of sustainable agriculture technology was carried out to provide understanding to farmers in the dryland of Gumantar Village, North Lombok Regency (KLU) about the importance of sustainable agriculture in order to maintain soil fertility and land productivity. The activity was carried out by making a demonstration plot of aerobic composting of mungbean waste and then followed by an in-situ test of the benefits of compost for chili plants. As a comparison, plots were made for planting chili plants without compost treatment. Aerobic composting was done by using BeKa decomposer (PT. Indo Acidatama Tbk). Several formal and informal meetings were held with farmers to increase their understanding of sustainable agriculture. The results of the activities indicated that the target farmers did not understand at all about sustainable agriculture. The good news was that the farmers passionate about understanding the benefits of sustainable agriculture. At the end, the participants understanding and beliefs about sustainable agriculture improved after seeing the yields of chili plants in the compost treatment which were much higher than those without compost treatment.

Keywords: aerob; enthusiast; decomposer; fertility; compost

Abtrak: Kendala utama yang dihadapi dalam pengembangan tanaman semusim di lahan kering adalah ketersediaan air dan tingkat kesuburan tanah yang rendah. Akibatnya, indeks pertanaman (IP) lahan kering sangat rendah karena kebanyakan hanya ditanami pada musim penghujan saja. Selain itu, penggunaan pupuk anorganik menjadi sangat tinggi untuk memperoleh hasil tanaman yang memadai. Praktek seperti ini dapat mengakibatkan berkurangnya kandungan karbon organik di dalam tanah dalam jangka panjang. Kesuburan tanah dapat terjaga apabila tanahnya banyak mengandung karbon organik. Karbon organik di dalam tanah dapat meningkatkan kesuburan tanah dengan mencegah kehilangan nutrisi, meningkatkan stabilitas fisik tanah, meningkatkan kemampuan tanah menahan air dan meningkatkan konsorsium mikroorganisme. Kegiatan pengenalan teknologi pertanian yang berkelanjutan dilakukan untuk memberikan pemahaman kepada petani di lahan kering Desa Gumantar, Kabupaten Lombok Utara (KLU) tentang 
pentingnya pertanian berkelanjutan dalam rangka menjaga kesuburan dan produktivitas lahan. Kegiatan dilakukan dengan membuat demonstrasi plot pengomposan limbah tanaman kacang hijau secara aerobik dan selanjutnya dilakukan uji in-situ manfaat kompos bagi tanaman cabai. Sebagai pembanding, dibuatkan petak penanaman tanaman cabai tanpa perlakuan kompos. Pengomposan secara aerobik dilakukan dengan menggunakan dekomposer $\mathrm{BeKa}$ (PT. Indo Acidatama Tbk). Beberapa pertemuan formal dan informal dilakukan dengan petani untuk meningkatkan pemahaman mereka terhadap pertanian berkelanjutan. Hasil kegiatan menunjukkan bahwa petani target belum paham sama sekali tentang pertanian berkelanjutan. Hal yang menggembirakan adalah bahwa mereka memiliki antusiasme yang tinggi untuk memahami manfaat dari pertanian berkelanjutan. Pada akhirnya, pemahaman dan keyakinan peserta tentang pertanian berkelanjutan meningkat setelah mereka melihat hasil tanaman cabai pada perlakuan kompos yang jauh lebih tinggi dibandingkan dengan yang tanpa kompos.

Kata Kunci: aerob; antusias; decomposer; kesuburan; kompos

\section{PENDAHULUAN}

Desa Gumantar, Kecamatan Kayangan, Kabupaten Lombok Utara (KLU) adalah merupakan kawasan lahan kering. Seperti di kawasan lahan kering KLU pada umumnya, petani di desa ini menanam tanaman pangan seperti jagung, kacang tanah, kacang hijau, dan ubi jalar pada musim penghujan. Secara umum Indeks Pertanaman (IP) lahan kering di wilayan Gumantar adalah 100. Namun akhir-akhir ini, petani di desa ini juga mengusahakan tanaman hortikultura, seperti cabai, tomat, terung dan melon pada musim penghujan. Hal ini dimungkinkan karena sebagian besar lahan didominasi oleh fraksi pasiran, atau lempung pasiran sehingga air hujan tidak menggenang, Namun di satu sisi, tingkat kesuburan tanahnya sangat rendah karena rendahnya kandungan karbon organik di dalam tanah (Jaya et al, 2020). Akibatnya, untuk mendapatkan hasil tanaman yang optimal, dibutuhkan pupuk anorganik dalam jumlah yang sangat besar. Terlepas dari kelemahan rendahnya tingkat kesuburan tanah yang dimiliki, lahan kering mempunyai keunggulan untuk dapat berproduksi di luar musim sehingga memperoleh harga produk yang jauh lebih tinggi.

Pada musim kemarau, petani sangat bergantung pada hasil tanaman tahunan mereka seperti mangga dan kelapa. Akhir-akhir ini cukup banyak petani yang dapat menanam tanaman hortikultura pada musim kemarau karena sudah tersedia sarana air irigasi dalam jumlah yang terbatas. Meskipun terbatas, ketersediaan air pada musim kemarau tersebut sudah dapat sedikit meningkatkan Indeks Pertanaman (IP) di wilayah tersebut. Dengan keterbatasan air irigasi ini tentunya akan berdampak terhadap kualitas produk hortikultura yang dihasilkan, karena kita tahu kalau produk hortikultura itu berkualitas karena kandungan airnya yang tinggi. Sementara itu, pada musim penghujan, dengan pola curah hujan yang erratic sebagai akibat dari terjadinya perubahan iklim, sering kali hujan hilang dalam kurun waktu yang cukup lama (Jaya et al, 2020) atau air berlebih. Air hujan yang berlebih ini berpotensi untuk menghanyutkan unsur hara yang ada di dalam tanah. Langkah-langkah untuk dapat meningkatkan kualitas produksi tanaman hortikultura dan membuat praktek budidaya tanaman secara umum di Desa Gumantar yang berkelanjutan perlu untuk dilakukan.

Secara teori, air irigasi di lahan pasiran dapat diefisienkan penggunaannya dengan meningkatkan kapasitas menahan air (water holding capacity) oleh tanah (Basso et al, 2013). Teori lain mengatakan bahwa sampah organik yang berasal dari sistim pertanian dapat digunakan sebagai bahan pembenah tanah yang mengandung karbon organik tinggi sehingga dapat meningkatkan kapasitas tanah untuk menahan air (Mubarak et al., 2009). Dua teori yang disebutkan terdahulu dapat 
dijadikan landasan untuk membantu meningkatkan kemampuan tanah menahan air sehingga dapat meningkatkan Indeks Pertanaman. Dampak lainnya adalah terjadinya peningkatan kualitas produk tanaman, khususnya tanaman hortikultura. Hal ini dimungkinkan karena terdapat banyak sekali limbah pertanian yang dihasilkan dari tanaman-tanaman yang diusahakan pada musim penghujan. Biasanya sisa-sisa tanaman tersebut dibakar atau ditumpuk begitu saja di sekitar lahan. Selain itu, petani di lahan kering di dusun Amor-amor juga banyak yang memelihara ternak, seperti sapi dan kambing. Limbah ternak petani dapat juga dijadikan sumber bahan organik untuk selanjutnya diolah menjadi pupuk organik.

Hambatan terbesar petani dalam mengolah bahan organik (sisa-sisa tanaman dan kotoran ternak) menjadi pupuk organik adalah tempat dan tenaga kerja. Hal ini terjadi karena decomposer yang digunakan membutuhkan kondisi anaerob (tanpa oksigen) untuk melakukan proses dekomposisi. Selain itu, petani harus menambahkan larutan gula dan urea agar konsorsium mikroba dapat bekerja dengan baik dan kompos atau pupuk organik yang dihasilkan mengandung nitrogen yang tinggi. Kegiatan membolak-balik bahan organik selama proses pengomposan juga harus dilakukan. Hal inilah yang membuat petani enggan untuk mengembalikan bahan organik yang merupakan limbah pertanian mereka sendiri ke lahan mereka. Semua persoalan petani dalam membuat pupuk organik dari limbah pertanian mereka sebenarnya dapat diatasi dengan menggunakan dekomposer plus yang mengandung konsorsium mikroba dan pembenah tanah.

Keunggulan dekomposer plus ini adalah bahwa konsorsium mikrobanya bekerja pada kondisi aerob (dengan oksigen) sehingga tidak harus dibuatkan tempat yang khusus dan tidak harus dibalikbalik dan tidak juga harus ditambahkan urea. Konsorsium mikroba yang terdapat dalam decomposer plus adalah Bacillus sp sebanyak $1,1 \times 10^{8} \mathrm{cfu} / \mathrm{ml}$, Trichoderma sp sebanyak $3,4 \times 10^{7} \mathrm{cfu} / \mathrm{ml}$, Aspergillus sp $7,3 \times 10^{7} \mathrm{cfu} / \mathrm{ml}$, Streptomyces sp $2,4 \times 10^{8} \mathrm{cfu} / \mathrm{ml}$ dan $\mathrm{pH} 6,9$. Hasil proses dekomposisinya juga mengandung unsur hara makro, seperti N, P dan K serta karbon organik tanah yang tinggi dan mengandung unsur hara mikro $\mathrm{Ca}, \mathrm{Mg}, \mathrm{Si}, \mathrm{Fe}, \mathrm{Mn}, \mathrm{Mo}, \mathrm{B}, \mathrm{Cl}, \mathrm{Zn}$, dan $\mathrm{Cu}$ disertai asam humat dan asam fulfat yang dapat mengembalikan kesuburan tanah. Dengan hasil kompos seperti ini maka tanah akan mampu meningkatkan kapasitas tukar kationnya (KTK) dan kemampuannya menahan air atau water holding capacity (https: // www. acidatama.co.id/produkagro.php?id=5, https://www.acidatama.co.id/ product-agro.php? id =6). Merek dagang dari dekomposer plus yang sekaligus berperan sebagai bahan pembenah tanah adalah BeKa Decomposer Plus, produksi PT. Indo Acidatama Tbk dengan nomor pendaftaran di Deptan: 03.02.2013.014.

Jika dilihat dari nomor pendaftarannya di Deptan, produk BeKa Decomposer Plus ini sudah cukup lama beredar di pasaran. Di Sembalun Kabupaten Lombok Timur, produk ini pernah diberikan secara cuma-cuma oleh pemerintah pada sekitar tahun 2016-2016 kepada petani sayuran, tetapi saat itu tidak dibarengi dengan pelatihan dan pengawalan tentang cara pemakaiannya. Akhirnya BeKa Decomposer Plus tidak pernah lagi digunakan. Penulis utama juga sudah melakukan uji coba penggunaan BeKa di Gumantar pada tahun 2020 untuk meningkatkan produktivitas tanaman jagung. Tugas akademisi adalah memberikan penyuluhan dan pendampingan pemanfaatan teknologi baru, apalagi teknologi baru tersebut diyakini dapat meningkatkan kesejahteraan masyarakat dan membuat sistim pertanian bisa berkelanjutan. Tujuan dari kegiatan pengabdian kepada masyarakat ini adalah untuk memperkenalkan konsep pertanian berkelanjutan di lahan kering desa Gumantar, Lombok Utara dengan cara menerapkan dan mengawal teknik merubah bahan organik yang berasal dari limbah pertanian menjadi pupuk organik menggunakan BeKa Decomposer Plus yang sekaligus berperan sebagai bahan pembenah tanah. 


\section{METODE}

Metoda kegiatan yang dilakukan meliputi empat tahapan, yaitu: survey lokasi, penyiapan kompos, penyiapan demo plot dan kegiatan penyuluhan dan tahap terakhir adalah evaluasi.

\section{A. Survey Lokasi}

Langkah awal dari kegiatan pengabdian kepada masyarakat ini adalah melakukan survey, yang meliputi kondisi lahan, potensi produktivitas lahan dan tanaman, potensi sumber pengairan, potensi limbah pertanian dan potensi sumber daya manusia. Langkah selanjutnya adalah melakukan diskusi dengan ketua dan sekretaris kelompok tani mitra, yaitu Kelompok Tani Lembah Telaga, mengenai kegiatan-kegiatan yang sudah dilakukan dan kegiatan-kegiatan yang ingin dilakukan oleh petani di masa yang akan datang. Selanjutnya, oleh ketua kelompok ditugaskan sekretaris kelompok untuk mengkoordinir kegiatan bersama Tim Penyuluh. Peluang untuk menyampaikan masalah tentang pengelolaan limbah pertanian untuk dijadikan kompos dalam rangka mendukung program pertanian berkelanjutan di lahan kering, juga ditanyakan dan disampaikan. Setelah ada pemahaman dari sekretaris kelompok tani dan kesediaan untuk berpartisipasi dalam kegiatan pengabdian kepada masyarakat yang direncanakan, selanjutnya disusun rencana untuk membuat lokasi demonstrasi pengomposan dan sekaligus demonstrasi plot. Peserta penyuluhan yang ditargetkan adalah sebanyak 30 orang.

\section{B. Penyiapan Kompos}

Tahapan berikutnya adalah melakukan persiapan-persiapan dalam membuat kompos dan bahan-bahan peraga pada saat kegiatan penyuluhan. Lokasi pengomposan ditetapkan di sebidang lahan sekitar 5 are yang sebelumnya ditanami kacang hijau. Sisa tanaman kacang hijau ini kemudian dijadikan materi untuk dikomposkan dengan proses pengomposan secara aerobik. Permukaan tanah yang sudah tercampur dengan sisa biomassa tanaman kacang hijau disemprot secara merata dan cukup basah dengan larutan dekomposer BeKa Plus (konsentrasi 1,6\%). Kegiatan pengomposan dikoordinir oleh sekretaris kelompok yang melibatkan beberapa orang anggota kelompok tani. Selama proses pengomposan yang berlangsung sekitar tiga (3) minggu, Tim Penyuluh berkesempatan hadir untuk memantau proses dekomposisi limbah tanaman kacang hijau dan berdiskusi dengan anggota kelompok tani yang berkesempatan hadir di lokasi pengomposan. Bibit tanaman cabai dipersiapkan pada period ini.

\section{Penyiapan Demo Plot dan Kegiatan Penyuluhan}

Setelah proses pengomposan selesai, langkah-langkah berikutnya adalah sebagai berikut. Pertama, lahan dibongkar kembali menggunakan traktor untuk memastikan kompos tercampur merata dengan tanah dan setelah itu barulah dibuat bedeng-bedeng tempat penanaman cabai. Sebelum ditutup dengan mulsa plastik, pupuk dasar yang berupa NPK Phonska dengan dosis $750 \mathrm{~kg} / \mathrm{ha}$ diaplikasikan di tengah-tengan masing-masing bedeng, dan ditutup tipis dengan tanah. Selanjutnya barulah mulsa dipasang, dibuatkan lobang tanam dengan jarak 50 x $50 \mathrm{~cm}$ dan dilakukan penanaman bibit pada tanggal 16 Mei 2020. 


\section{Tahap Evaluasi}

Evaluasi keberhasilan kegiatan dilaksanakan berdasarkan pada antuasiasme peserta dalam diskusi, kunjungan anggota kelompok tani ke lokasi demplot dan perbandingan tampilan tanaman antara yang diperlakukan dengan kompos dengan yang tidak diperlakukan. Tindak lanjut kegiatan adalah melakukan pengamatan prilaku petani selanjutnya dalam memanfaatkan limbah pertanian mereka untuk dijadikan kompos sehingga menjadi praktek budidaya tanaman yang berkelanjutan di lahan kering. Kandungan karbon organik dan populasi bakteri serta jamur di dalam tanah yang diperlakukan dengan kompos dan yang tidak diperlakukan juga dibandingkan.

\section{HASIL DAN PEMBAHASAN}

Tujuan dari kegiatan ini adalah untuk menerapkan teknik pengomposan limbah pertanian menjadi kompos dan memanfaatkan kompos tersebut untuk mendukung pertanian berkelanjutan di lahan kering. Dengan tujuan tersebut dan mengacu pada tahapan yang sudah dipaparkan sebelumnya, maka hasil kegiatan dapat dilaporkan sebagai berikut.

\section{A. Hasil Survey Lokasi}

Sebidang lahan di Dusun Amor-amor Desa Gumantar terpilih sebagai tempat lokasi untuk melakukan proses pengomposan dan melaksanakan demonstrasi plot. Lahan tersebut terletak di pinggir jalan dan memiliki akses pengairan secara terbatas, namun cukup untuk mendukung pertumbuhan tanaman cabai. Lokasi tersebut cukup strategis karena sangat berdekatan dengan rumah sekretaris kelompok tani yang memiliki halaman cukup luas dan beratap, yang sangat cocok digunakan sebagai tempat pertemuan. Pada saat survey dilakukan di bulan Mei 2020, lahan tersebut sedang ditanamai kacang hijau dan sudah siap panen.

\section{B. Hasil Kompos}

Proses pengomposan berjalan dengan baik dan tanpa harus membolak balik tanah ataupun memindahkan kompos dari satu tempat ke tempat yang lain. Pada saat proses pengomposan berlangsung (selama 3 minggu sesuai dengan rencana), Tim Penyuluh sempat berkunjung dan melakukan diskusi dengan sekretaris kelompok dan beberapa orang petani yang tertarik untuk mendiskusikan proses pengomposan yang sedang berlangsung.

\section{Hasil Demo Plot dan Kegiatan Penyuluhan}

Secara umum semua tanaman tumbuh subur, baik pada perlakuan dengan kompos maupun tanpa kompos, namun tanaman dengan perlakuan kompos terlihat lebih besar dan lebih hijau (Gambar 1). Ada indikasi bahwa lahan yang mendapatkan perlakuan kompos lebih subur dari lahan tanpa kompos.

Kegiatan penyuluhan secara formal dilakukan pada tanggal 19 Juli 2020 pada saat tanaman berumur 64 hari setelah tanam (hst). Sebelum kegiatan penyuluhan dan kunjungan ke demonstrasi plot, kondisi tanaman diperiksa sehingga selanjutnya bisa dijelaskan dengan benar kepada para petani tentang kondisi dan permasalahan yang ada. Dari hasil pemeriksaan yang melibatkan rekan dosen yang memiliki keahlian di bidang Epidemiologi, diketahui bahwa tanaman cabai terserang virus kuning keriting, baik pada perlakuan kompos maupun pada perlakuan tanpa kompos. Hanya saja tanaman pada perlakuan tanpa kompos mengalami gangguan virus yang lebih parah dari tanaman 
tanpa kompos, seperti terlihat pada Gambar 1. Selain virus, diidentifikasi juga vektor pembawa virus ke tanaman cabai, yaitu kutu kebul dan aphis yang mengakibatkan daun-daun tanaman cabai berwarna hitam. Namun secara keseluruhan, tanaman cabai tumbuh dengan baik dan sekretaris kelompok tani Lembah Telaga sangat puas dengan tampilan tanaman cabai pada perlakuan kompos.
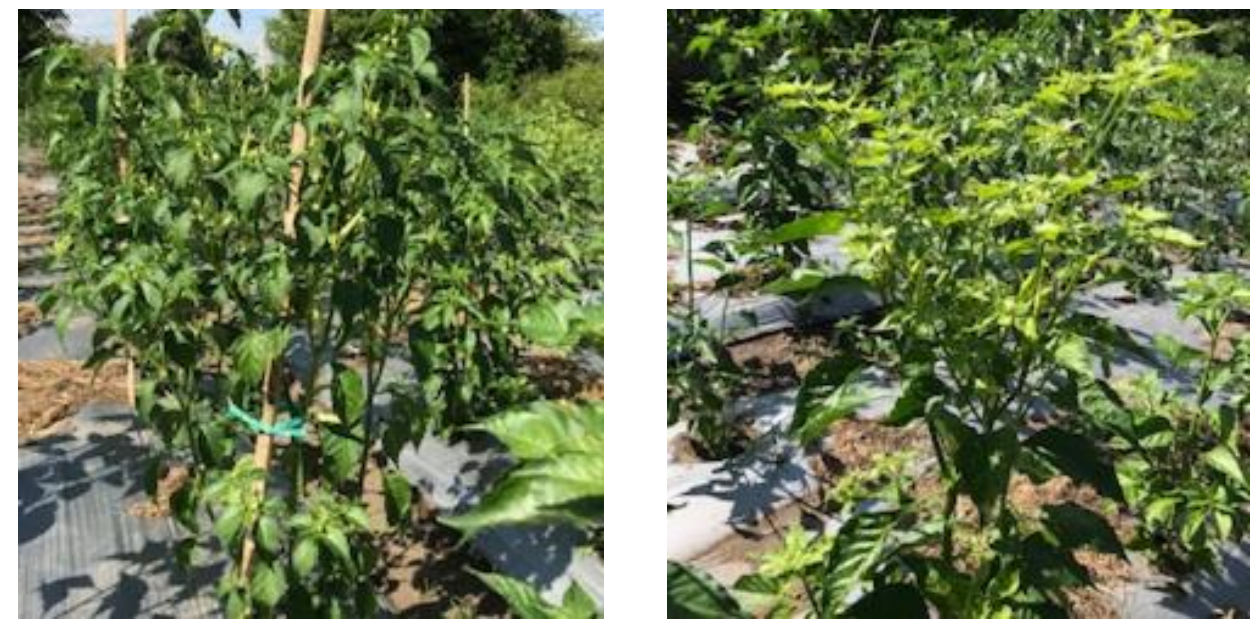

Gambar 1 Tampilan tanaman cabai dengan perlakuan kompos (kiri) dan tanpa perlakuan kompos (kanan) pada umur 56 hari setelah tanam.

Setelah kegiatan inspeksi lapang oleh Tim Penyuluh dan tenaga ahli, kemudian kegiatan penyuluhan secara formal dimulai. Jumlah petani yang hadir pada kegiatan penyuluhan tersebut adalah sebanyak 32 orang. Jumlah ini melebihi jumlah undangan yang disebar sebanyak 30 undangan. Karena pada saat kegiatan sedang dalam masa pandemi Covid-19, maka Tim Penyuluh menyiapkan masker bagi peserta yang tidak memakai masker dan juga menyiapkan tempat untuk mencuci tangan sebelum masuk ke tempat pertemuan (Gambar 2). Semua peserta dan Tim Penyuluh diwajibkan mematuhi Protokol Kesehatan (PROKES) dengan baik. Kegiatan penyuluhan dibuka oleh Dekan Fakultas Pertanian Universitas Mataram, bapak Ir. Sudirman, M.Sc., Ph.D. Kegiatan penyuluhan juga dihadiri oleh distributor dari produk decomposer BeKa Plus yang juga memberikan sumbangan beberapa botol dekomposer tersebut kepada petani yang hadir.

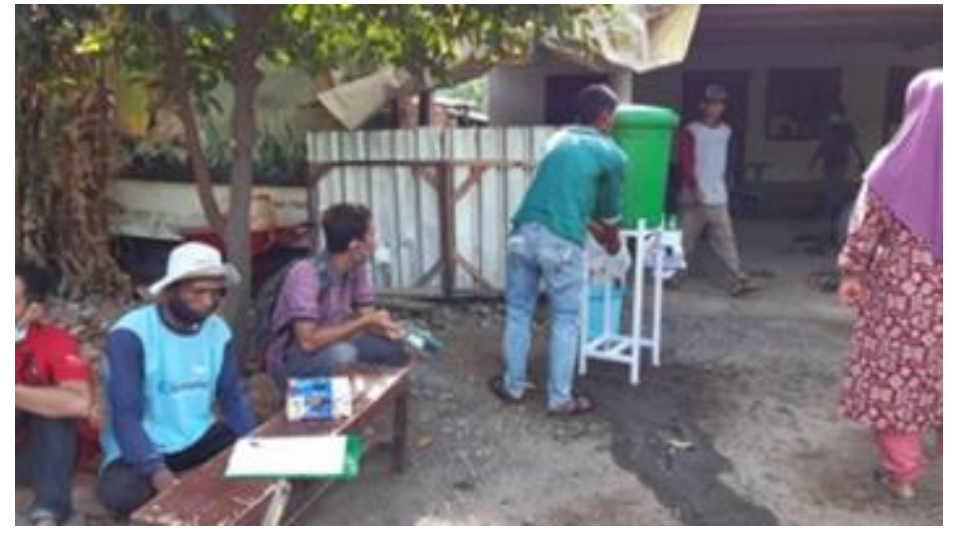

Gambar 2 Pemberian masker dan kegiatan mencuci tangan sebelum masuk ke tempat penyuluhan 
Setelah kegiatan penyuluhan dibuka, penyuluh mulai dengan pertanyaan yang menanyakan pengetahuan peserta tentang pertanian berkelanjutan (Gambar 3). Di luar dugaan, tidak satupun dari peserta yang hadir megetahui apa yang dimaksud dengan pertanian berkelanjutan. Dengan kondisi seperti itu, penyuluh berusaha mencari beberapa contoh yang mudah dipahami oleh mereka. Salah satu contoh kasus yang diberikan adalah tingginya dosis pupuk yang digunakan untuk dapat menghasilkan jagung yang optimal. Meskipun sudah menggunakan dosis pupuk yang tinggi, kalau terjadi kondisi curah hujan menghilang sekitar dua atau tiga minggu di musim penghujan (dry spell), seperti pada musim penghujan tahun 2016/2017, maka hampir semua tanaman jagung mengalami gagal panen. Hal ini terjadi karena tanah mereka di lahan kering sangat sedikit kemampuannya mengikat air sebagai akibat rendahnya kandungan bahan organik di dalam tanah. Dengan penjelasan tersebut, semua peserta membenarkan kasus yang terjadi pada musim penghujan 2016/2017 tersebut.

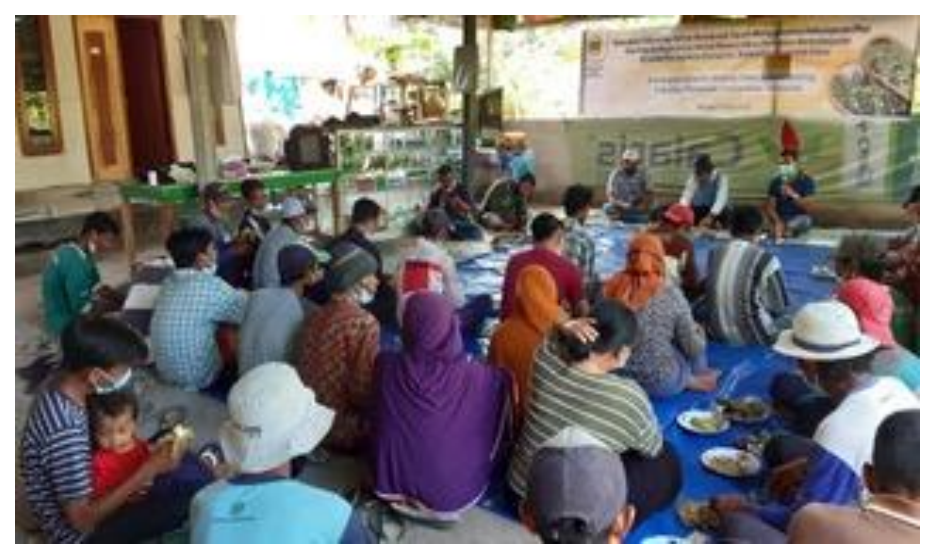

Gambar 3 Suasana kegiatan penyuluhan yang diikuti oleh 32 orang petani

Penjelasan kasus tersebut kemudian menjadi titik masuk bagi penyuluh untuk menyampaikan arti pentingnya pertanian berkelanjutan di lahan kering di Desa Gumantar. Sementara itu, di pihak peserta, mereka menunjukkan antusiasme yang tinggi untuk mengikuti kegiatan penyuluhan dan diskusi karena permasalahan yang mereka hadapi dibahas pada pertemuan tersebut. Penyuluh menjelaskan bahwa tingkat kesuburan tanah di lahan kering di Gumantar umumnya, sangat rendah. Oleh karena itu petani selalu membutuhkan dosis pupuk yang tinggi untuk memperoleh hasil yang maksimal. Terkadang, kebutuhan pupuk tersebut tidak dapat terpenuhi karena ketersediaan pupuk yang terbatas. Pada saat pupuk anorganik, seperti urea dan NPK Phonska tersedia dalam jumlah yang banyak, aplikasi pupuk tersebut sebenarnya berdampak negatif terhadap kesuburan tanah dalam jangka panjang. Pesertapun menyadari bahwa dari tahun ke tahun jumlah masukan pertanian yang digunakan (seperti herbisida, pestisida dan pupuk) semakin banyak. Beberapa peserta mengungkapkan bahwa selain pupuk yang banyak dibutuhkan, pestisida juga semakin meningkat kebutuhannya.

Selanjutnya penyuluh menjelaskan bahwa salah satu dampak dari penggunaan masukan pertanian yang tinggi adalah terjadinya ketidak seimbangan ekosistem di lingkungan pertanian. Penyuluh memberikan contoh tentang gangguan virus pada tanaman cabai di lokasi demonstrasi plot. Adanya serangan virus tersebut salah satunya disebabkan karena musuh alami dari kutu kebul dan aphis (vektor virus), yaitu laba-laba dan tawon hampir tidak ada di pertanaman. Hal ini terjadi karena penggunaan pestisida yang intensif di lingkungan desa Gumantar yang sudah mulai mengusahakan 
cukup banyak tanaman hortikultura. Oleh karena itu sangat penting untuk menerapkan konsep pertanian berkelanjutan.

Inti dari konsep pertanian berkelanjutan adalah, kebutuhan pangan dan sandang petani dan keluarganya saat ini bisa terpenuhi dari kegiatan bertani dan lahan yang digunakan saat ini, dapat juga digunakan oleh anak cucu mereka di kemudian hari untuk memenuhi kebutuhan pangan dan sandangnya dan kesehatan tanah tetap terjaga (Lichtfouse et al, 2009; Gomiero et al, 2011). Hal ini tidak bisa tercapai dengan menerapkan teknologi pertanian secara konvensional dan mereka sudah merasakan bahwa biaya produksi terus meningkat sehingga keuntungan yang diperoleh semakin sedikit. Hambatan lain yang petani harus hadapi adalah adanya pengaruh dari perubahan iklim, seperti curah hujan yang tidak bisa diprediksi dan kemungkinan ledakan hama dan penyakit tanaman. Penjelasan tersebut telah membuat peserta penyuluhan paham tentang konsep pertanian berkelanjutan. Dalam jangka panjang, perubahan yang diharapkan terjadi adalah tentang paradigma dan nilai-nilai mereka dalam mengelola lahan.

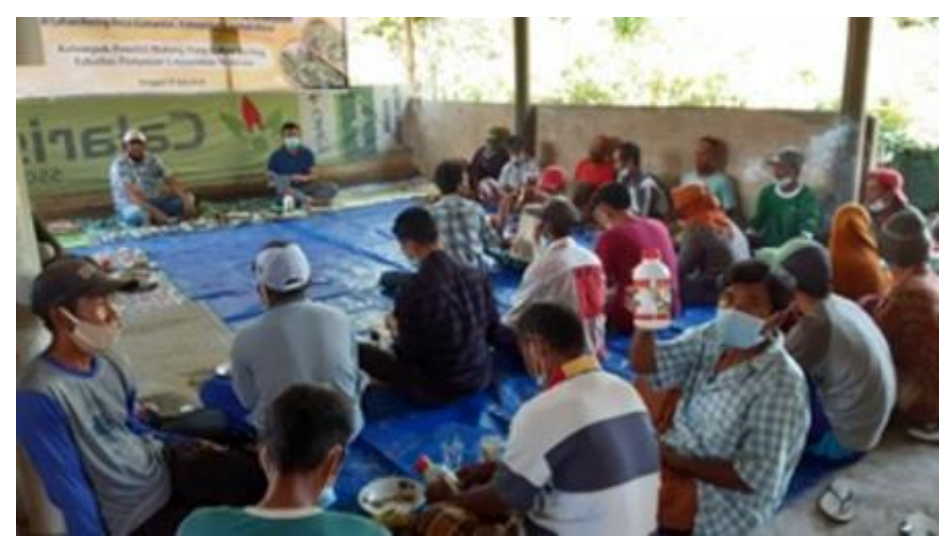

Gambar 4 Seorang petani menunjukkan sebotol dekomposer yang diterima dari Tim Penyuluh dan yang lain sedang menyimak komposisi dari dekomposer.

Dengan dipahaminya konsep pertanian berkelanjutan, maka selanjutnya adalah menjelaskan tentang salah satu praktek penerapan teknologi pertanian berkelanjutan. Penyuluh menjelaskan bahwa salah satu penyebab tinggiya dosis pupuk yang harus diaplikasikan adalah rendahnya kandungan karbon organik di dalam tanah (Powlson et al, 2011). Karbon organik itu sendiri, yang dapat diaplikasikan dalam bentuk kompos, sebenarnya dapat dihasilkan oleh petani dengan memanfaatkan limbah pertanian yang ada. Persoalannya sekarang adalah kegiatan untuk menghasilkan kompos masih dianggap sesuatu yang merepotkan karena beberapa alasan. Pertama, harus mengangkut limbah pertanian ke suatu tempat; kedua, harus mencacah bahan tersebut; ketiga, harus menambahkan urea dan larutan gula ke materi yang akan dikomposkan; keempat, dalam proses dekomposisi harus sering membolak balik materi; dan kelima, harus mengembalikan kompos yang sudah jadi ke lahan. Hal inilah yang menjadi kendala dalam pembuatan kompos oleh petani. Sementara itu, dengan teknologi dekomposer Beka Plus yang proses dekomposisinya berlangsung secara aerobik, petani merasa sangat ringan untuk melakukan. Oleh karena itulah selanjutnya petani dengan antusiasme yang tinggi ingin mencoba sendiri melakukan salah satu praktek pertanian berkelanjutan dengan membuat kompos dari limbah pertanian mereka. Mereka sangat berharap dapat diberikan dokomposer BeKa Plus untuk mereka coba. 
Tim Penyuluh dan salah satu pihak mitra, distributor dari dekomposer BeKa, memberikan bantuan 20 botol (1 botol berisi 1 liter) BeKa kepada petani peserta. Bagi yang tidak memperoleh BeKa, penyuluh memberikan 20 botol pupuk daun organik Pomi untuk mengurangi penggunaan pupuk anorganik pada tanaman sayuran. Petani sangat senang menerima bantuan tersebut (Gambar 4) dan mengatakan siap untuk mencoba membuat kompos dan mengaplikasikan pupuk daun organik Pomi. Kegiatan penyuluhan diakhiri dengan melakukan kunjungan ke demonstrasi plot bagi petani yang belum sempat mengunjungi tanaman cabai yang dipersiapkan oleh Tim Penyuluh Bersama dengan sekretaris kelompok tani Lembah Telaga.

\section{Hasil Evaluasi}

Evaluasi dilaksanakan berdasarkan antusiasme peserta dalam mengikuti kegiatan penyuluhan, kunjungan ke demonstrasi plot, tampilan tanaman, kegiatan mempraktekkan pembuatan kompos dari limbah pertanian serta kandungan karbon organik dan mikroorganisme tanah. Antusiasme petani sasaran dalam mengikuti kegiatan penyuluhan dapat dilihat dari tingkat kehadiran peserta. Undangan diberikan kepada 20 orang petani dari anggota kelompok tani Lembah Telaga ditambah 10 orang dari tiga (3) dusun yang berbeda yang ada di Desa Gumantar. Meskipun masih dalam suasana Pandemi Covid-19, jumlah peserta yang hadir adalah 32 orang dan cukup banyak yang aktif bertanya dan menyampaikan komentar karena masalah yang dibahas adalah masalah yang mereka hadapi saat ini.

Untuk kegiatan kunjungan ke demonstrasi plot, Tim Penyuluh tidak sempat mendokumentasikan kegiatannya, tetapi menurut keterangan sekeretaris kelompok tani yang bertanggung jawab atas demonstrasi plot yang dibuat, cukup banyak petani yang berkunjung ke lokasi demo. Bahkan ada beberapa petani yang berkunjung lebih dari satu kali terutama pada saat panen. Mereka pada umumnya heran melihat tampilan tanaman cabai di lokasi demostrasi plot yang masih bertahan dan berproduksi padahal tanaman petani sudah banyak yang mati sebagai akibat serangan virus kuning dan keriting serta serangan hama kutu kebul dan aphis.

Evaluasi untuk kegiatan praktek membuat kompos dilakukan berdasarkan aktivitas peserta penyuluhan dalam membuat kompos dan mengaplikasikan pupuk daun organik Pomi. Hampir semua petani peserta sudah mencoba teknologi yang disampaikan pada saat penyuluhan, meskipun hasilnya ada yang menggembirakan dan ada pula yang mengatakan belum signifikan hasilnya. Hal ini dapat dimaklumi karena kegiatan praktek pertanian berkelanjutan tidak dapat menghasilkan hasil secara instan dan butuh waktu beberapa tahun agar dampaknya terlihat nyata (Diacono and Montemurro, 2010).

Dari segi kandungan karbon organik tanah yang diamati pada saat panen pertama, kandungan karbon organik pada perlakuan kompos adalah 0,91\% sedangkan pada perlakuan tanpa kompos kadungannya $0,68 \%$. Data ini menunjukkan bahwa ada peningkatan kandungan karbon organik tanah sebesar 25\% dengan menerapkan teknologi pertanian berkelanjutan, yaitu aplikasi kompos yang bahan bakunya berasal dari limbah pertanian. Peningkatan kandungan karbon organik tanah ini dalam jangka waktu yang panjang dapat meningkatkan kesuburan tanah, meningkatkan efisiensi pemupukan, meningkatkan kemampuan tanah menahan air serta meningkatkan konsorsium mikroba di dalam tanah (Lal, 2007).

Jumlah koloni bakteri pada perlakuan kompos adalah $23 \times 10^{11} \mathrm{koloni} / \mathrm{ml}$, sedangkan pada perlakuan tanpa kompos jumlahnya adalah $3 \times 10^{11} \mathrm{koloni} / \mathrm{ml}$. Dalam hal kerapatan jamur, pada perlakuan kompos kerapatannya adalah $6,73 \times 10^{4} \mathrm{CPU} / \mathrm{g}$ sampel sementara pada perlakuan tanpa kompos kerapatan koloni jamurnya adalah 3,40 x $10^{4} \mathrm{CPU} / \mathrm{g}$ sampel. Data ini menunjukkan bahwa 
memang terjadi peningkatan konsorsium mikroorganisme di dalam tanah yang diperlakukan dengan kompos. Dengan perubahan-perubahan yang terjadi, diharapkan tingkat kesuburan tanah di lahan kering Gumantar bisa meningkat sehingga Indeks Pertanaman juga dapat ditingkatkan.

\section{KESIMPULAN DAN SARAN}

\section{A. Kesimpulan} berikut:

Dari tahapan kegiatan yang sudah dilakukan maka dapat diambil beberapa kesimpulan sebagai

1. Petani di lahan kering desa Gumantar belum paham tentang konsep pertanian berkelanjutan namun menyadari praktek yang mereka lakukan saat ini hasilnya tidak memuaskan.

2. Ada antusiame yang tinggi dari peserta sasaran kegiatan pengabdian kepada masyarakat dalam menyimak dan mengikuti kegiatan karena yang dibahas adalah permasalahan yang mereka hadapi saat ini. Tingginya antusiasme petani menghasilkan pemahaman yang baik tentang konsep pertanian berkelanjutan.

3. Setelah mencoba membuat kompos sendiri, peserta mengatakan bahwa praktek pembuatan kompos secara aerobik sangat sederhana dan mudah dilakukan.

4. Ada peningkatan kesuburan tanah di lokasi demonstrasi plot sehingga tampilan tanaman dengan perlakuan kompos lebih baik dibandingkan tanpa kompos, meskipun di tingkat petani hasilnya belum semua bagus.

\section{B. Saran}

Disarankan supaya pendampingan dalam melaksanakan praktek budidaya tanaman secara berkelanjutan di lahan kering umumnya dan di Desa Gumantar khususnya, terus dilanjutkan untuk bisa mendapatkan hasil yang optimal. Hasil optimal yang dimaksud adalah terjadinya peningkatan kesuburan tanah dan peningkatan hasil tanaman yang bermuara pada peningkatan kualitas hidup masyarakat tani di lahan kering.

\section{Ucapan Terima Kasih}

Penulis mengucapkan terimakasih kepada Universitas Mataram yang telah mendanai kegiatan ini dengan Kontrak Nomor: 2194/UN18/LPPM/2020.

\section{DAFTAR PUSTAKA}

Basso, A. S., Miguez, F. E., Laird, D. A., Horton, R. and Westgate, M. 2013. Assessing potential of biochar for increasing water-holding capacity of sandy soils. Global Change in Bioenergy. vol 5, hal 132-143.

Diacono, M. and Montemurro, F. 2010. Long-term effects of organic amendments on soil fertility. A review. Agronomy for Sustainable Development. vol 30, hal 401-422.

Gomiero, T., Pimental, D., and Paoletti, G. 2011. Is there a need for a more sustainable agriculture? Critical Reviews in Plant Sciences. vol 30, hal 6-23.

Hoyle F.C., Baldock J.A., Murphy D.V. 2011. Soil Organic Carbon - Role in Rainfed Farming Systems, Tow P., Cooper I., Partridge I., Birch C. (eds): Rainfed Farming Systems. Springer, Dordrecht.

Ihwan, K., Sudika, I W. and Jaya, I K. D. 2019. Effect of two different planting patterns on performance of four maize varieties under rainfed conditions. AIP Conference Proceedings $2199,040003$. 
Jaya, I K. D., Sudirman, Rosmilawati, Soemeinaboedhy, I N. and Sudika, I W. 2020. Maize yield in a dryland area as affected by rainfall variability. IOP Conference Series: Earth and Environmental Science 411: 012067

Lal, R. 2008. Soils and sustainable agriculture. A review. Agronomy for Sustainable Development. vol 28, hal 57-64

Lichtfouse, E., Navarrete, M., Debaeke, P., Souchere, V., Alberola, C., and Měnassieu, J. 2009. Agronomy for sustainable agriculture. A review. Agronomy for Sustainable Development. vol 29, hal 1-6.

Mubarak, A. R., Ragab, O. E., Ali, A. A., and Hamed, N. E. 2009. Short-term studies on use of organic amendments for amelioration of a sandy soil. African Journal of Agricultural Research. vol 4, hal 621-627.

Olson, K. R., Al-Kaisi, M., Lal, R. and Cihacek, L. 2016. Impact of soil erosion on soil organic carbon stocks. Journal of Soil and Water Conservation. vol 71, hal 61A-67A.

Powlson, D. S., Gregory, P. J., Whalley, W. R., Quinton, J. N., Hopkins, D. W., Whitmore, A. P., Hirsch, P. R., and Goulding, K. W. T. 2011. Soil management in relation to sustainable agriculture and ecosystem services. Food Policy. vol 36, hal S72-S87.

Sainju, U. M., Jabro, J. D. and Stevens, W. B. 2008. Soil Carbon Dioxide Emission and Carbon Content as Affected by Irrigation, Tillage, Cropping System, and Nitrogen Fertilization. Journal of Environmental Quality. vol 37, hal 98-106. 